The Iraqi J. Vet. Med. Vol. 21, No. (1), 1997.

\title{
FREQUENCE OF JUXTAGLOMERULAR GRANULATED CELIS IN DEHYDRATED AND SODIUM-LOADED MICE
}

\author{
Imad M. Al-Ani * and Merza H. Homady* * \\ * Department of Biology, College of Science, Al-Mustansiriah \\ University, Baghdad, Iraq. \\ ** Department of Oral Pathology, College of Dentistry, \\ Baghdad, University, Baghdad, Iraq.
}

\section{SUMMARY}

Fifteen albino mice were subjected to three days dehydration and fifteen albino mice were given $1 \% \mathrm{NaCl}$ in their drinking water. Control animals were given drinking water.

All animals were sacrificed and kidneys were fixed in different fixatives and processed for light microscopy.

Section were stained for juxtaglomerular cells demonstration and the juxtaglomerular index (JGI) and percentage of granulated nephron(\%GN) were calculated. Kidneys from dehydrated and sodium-loaded animals showed significant decrease in both JGI and $\% \mathrm{GN}$ and was discussed in relation to renin secretion and release.

\section{INTRODUCTION}

It has been well established that most of the renin in the kidney is synthesized and stored in the myoepithelial cell of the afferent arterioles of the juxtaglomerular apparatus (JGA). Ultrastructural and immunocytochemical findings have demonstrated the presence of renin in these cells $(1,2,3)$. 


\section{The Iraqi J. Vet. Med. Vol. 21, No. (1), 1997.}

Renin is responsible for the production of Angiotensin I from plasma angiotensinogen ; the renin - angiotensin system is involved in a number of physiological activities including the maintenance of systemic arterial blood pressure, stimulation of aldosterone secretion from the zone glomerulosa of the adrenal cortex and the intra-renal control of glomerular filtration rate (4).

The juxtaglomerular index (JGI) expresses the frequency and degree of granulation of the juxtaglomerular cell " JGCs" $(5,6)$. A significant positive correlation between the JGI and the renin content of the kidney has been demonstrated (7).

An increase in the JGI was observed in the kidneys of patients with malignant hypertension (8), in rats with renal hypertension (9), in uninephrectomized rats (10), and in diuretic - treated mice (11).

It is supposed that the when an animal is placed in a dehydrated condition, the renin - angiotensin-aldosterone system (R-A-A-System) may function compensatorily and that JGCs may show morphological changes as their function changes (12). Sodium chloride has long been known to produce or exacerbate hypertension (10).

Sodium - loaded animals showed decreased number of granular celis in the JGA (13).

The present experiments were designed to evaluate the JGC and the percentage of gramulated nephrons (\%GN) of mice experimentally dehydrated and in mice drank $\mathrm{NaCl}$ containing water.

\section{MATERLALS AND METHODS}

Forty five male adult albino mico of average weight $25 \mathrm{gm}$ were used in this study. The animals were divided into three equal groups. Mice were kept in plastic cages ( 5 per cage) at 


\section{The Iraqi J. Vet. Med. Vol. 21, No. (1), 1997.}

room temperature. Group I (Control) were allowed free access to drinking water. Group II (Dehydrated)were deprived of drinking water for 3 days and sacrificed later. Group III Naloaded) were given $1 \% \mathrm{NaCl}$ in their drinking water for two weeks. All groups mice were fed a standard laboratory diet. The fluid intake of group III animals was measured at day 10-14. All animals were weighted at the beginning and end of the experiments.

Animals were killed by decapitation, transverse kidney slices were fixed in variety of fixatives $(10 \%$ formal saline, zenker formalin and Helly's fluid) and processed for light microscopy.

Sections of $5 \mathrm{~mm}$ thickness were stained specifically for JGCs demonstration with alkaline crystal violet (14), Bowie's method (15) and Endes's combined trichrome method (6). The JGI and $\%$ GN were calculated according to the method of Hartrof and Hartroft (5). The results obtained were statistically evaluated by Student's t-test.

\section{RESULTS}

Dehydrated and salt drinking animals showed a marked decreases in both JGI and \%GN (fig. 1). The mean value of JGI and $\% \mathrm{GN}$ of dehydrated animais was $(43.4 \pm 8.15)$ and $(29.2 \pm$ 6.6) respectively compared to that of controls $(70.46 \pm 12.46)$ and $(44.5 \pm 7.2)$. The difference was statistically significant $(P$ $<0.001$ ) (Table-1). The mean value of JGI and $\%$ GN of Naloaded animals was $(35.73 .6)$ and $(25.6 \pm 3.99)$ respectively compared to that of controls. The difference was statistically significant $(\mathrm{P}<0.001)$ (Table-1).

The average body weight of dehydrated mice was $20 \mathrm{gm}$; with a body weight loss equivalent to $20 \%$ of their initial body weight. The body weight of mice drinking $\mathrm{NaCl}$-containing 
The Iraqi J. Vet. Med. Vol. 21, No. (1), 1997.

water was similar to that of control, although their fluid intake increased to $14-15 \mathrm{ml} /$ day compared to $3-4 \mathrm{ml}$ day for control animals.

\section{DISCUSSION}

Earlier histochemical, ultrastructural and immunocytochemical studies have related the renin content to the myoepithelial cells in human $(1,3)$ and experimental animals (2). The JGI indicate the frequency and degree of granularity of the JGA. A significant relationship between renal renin concentration and JGI has been observed in normal and hypertensive rats ( 7 ). The present observations have shown a marked decreases in both JGI and \%GN in dehydrated animals and animals drank $\mathrm{NaCl}$-containing water. The decrease in JGI and $\% \mathrm{GN}$ in dehydrated animals supports earlier electron microscopical observations in dehydrated mice for 3 day (12). It was found that dehydration decreases the number of granules of juxtaglomerular cells (JGCs). It is assumed that the R-A-A System was activated during dehydration, probably between first and third day of dehydration (12). In normal animals; angiotensin stimulates secretion of antiduretic hormone (ADH), while $A D H$ reduces renin secretion (16). It is well known that water deprivation stimulates $\mathrm{ADH}$ secretion.

Plasma renin concentration (PRC) is elevated in rats with hereditary hypothalamic diabetes insipidus "with lack of ADH" and the morphological examination revealed well granulated myoepithelial cells which were sufficiently adapted for higher release of renin (7). In previous study (11) we related the increase in JGI in the diuretic treated mice to the activity of prostaglandins (Pgs). Infusion of PGE1 or PGE2 into dog renal artery caused an elevation in renin secretion (18). However, PGEs has no effect, whereas PGFs caused a decrease in renin 
The Iraqi J. Vet. Med. Vol. 21, No. (1), 1997.

release (19). Antidiuretic hormone stimulates renal production and excretion of PGEs and PGFs (20). Dehydration was found to reduced the granulation of the medullary interstitial cells (21) that synthesize and store prostaglandins in the kidney (22). Treatment of mice with saline is consistent with earlier morphological studies. Sodium-loaded animals have been shown to develop decreased granulation of JGC $(5,23)$.

There was evidence of decreased activity of the reninangiotensin system with fall in PRG and relatively poor myoepithelialioid cell granulation in sheep subjected to dietary sodium loading (24) and in rats drank $\mathrm{NaCl}$ containing water (10).

Sodium depletion results in an increase of PRC and ultrastructural changes of synthetic activity with a clear increase in JGI(24), correspondingly, at electron microscopic level, almost exclusively gramulated cells are found in afferent arterial and some even in the efferent arteriole of the sodium-depleted mouse (13).

It is still unclear as Tobian (25) had pointed in his review, whether an increase in JGGs shows that JGCs are hyperfunctional in both formation and secretion of renin or that these cells are merely involved in the storage stage.

Renin has been suggested to be secreted directly without passing the process of condensation into granular form ( 7 ).

Granules are very numerous in the mouse and rat, but progressively decrease in rabbit, cat, dog and monkey (26). The $\mathrm{JGC}$ are very sparse and poorly granulated in normal sheep (24) and $\operatorname{man}(27)$ and are non granulated in camels (The authors, unpublished data). Although the JGI correlates well with renal renin concentration (7), It dose not reflect the secretory activity of the JGC which can be determined either by measurement of 
The Iraqi J. Vet. Med. Vol. 21, No. (1), 1997.

PRC or by ultrastructural study of the JGC. Further ultrastructural studies in relation with PRC under the effect of sodium loading are needed.

Table 1 : Frequency of juxtaglomerular granulation in control, dehydrated and sodium - leaded mice.

\begin{tabular}{|c|c|c|c|c|c|c|}
\hline & \multicolumn{2}{|c|}{ Control } & \multicolumn{2}{c|}{ Dehydrated } & \multicolumn{2}{c|}{$\begin{array}{c}\text { Sodium } \\
\text { leaded }\end{array}$} \\
\hline & JG1 & $\% \mathrm{GN}$ & $\mathrm{JG} 1$ & $\% \mathrm{GN}$ & $\mathrm{JG} 1$ & $\% \mathrm{GN}$ \\
\hline \multirow{6}{*}{} & 62 & 41 & 52 & 30 & 48 & 28 \\
& 74 & 44 & 46 & 23 & 38 & 24 \\
& 60 & 39 & 38 & 24 & 21 & 19 \\
& 83 & 58 & 55 & 48 & 53 & 32 \\
& 61 & 49 & 41 & 22 & 40 & 29 \\
& 96 & 55 & 43 & 33 & 28 & 28 \\
& 70 & 49 & 50 & 32 & 41 & 29 \\
& 59 & 37 & 32 & 28 & 31 & 20 \\
& 65 & 38 & 46 & 23 & 40 & 27 \\
& 92 & 52 & 58 & 37 & 51 & 30 \\
& 55 & 36 & 37 & 25 & 31 & 24 \\
& 73 & 43 & 48 & 28 & 28 & 26 \\
& 67 & 36 & 37 & 26 & 30 & 25 \\
& 60 & 40 & 36 & 29 & 31 & 24 \\
& 80 & 51 & 32 & 30 & 25 & 19 \\
\hline \multirow{2}{*}{ Mean } & 70.46 & 44.5 & 43.4 & 29.2 & 29.2 & 25.6 \\
\cline { 1 - 2 } S.D & \pm & \pm & \pm & \pm & \pm & \pm \\
& 12.46 & 7.2 & 8.15 & 6.6 & 9.6 & 3.99 \\
\cline { 2 - 5 } & & & $\mathrm{P}<0.001$ & $\mathrm{P}<0.001$ \\
\hline
\end{tabular}


Figure 1 the $J G 1$ and $\% G \mathrm{~N}$ of contro!

(C), dehydrated (D) ant sodium - louded (N) Mice,

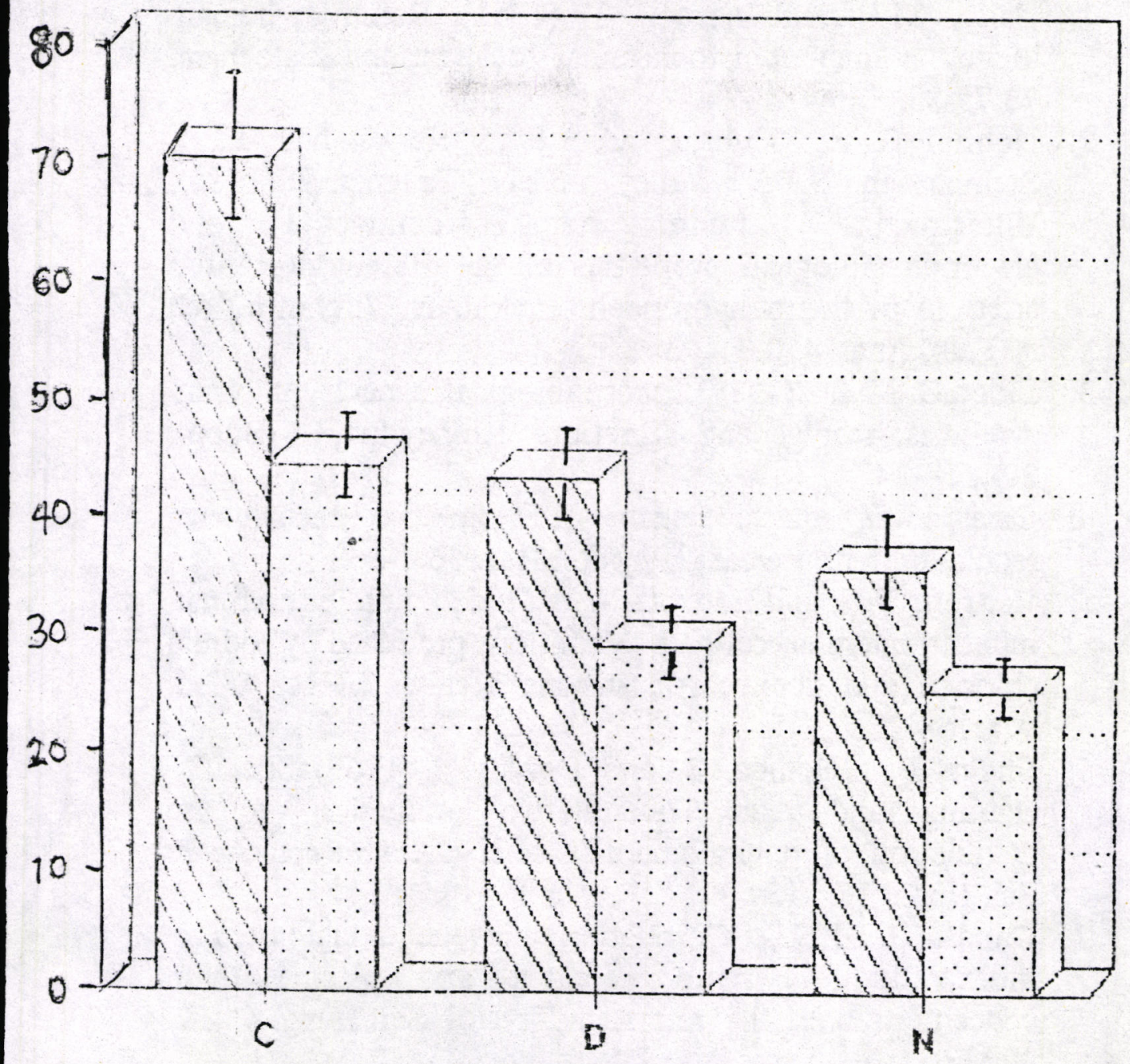

DI $\square$ व 
The Iraqi J. Vet. Med. Vol. 21, No. (1), 1997.

\section{REFERENCES}

1. Celio, M.R. and Inagami, T. (1981). Renin in human kidney : Immunohistochemical localization. Histochem. 73:75-88.

2. Nobiling,R. ; Buhrle, C. P. ; Hackenthal, E. ; Steinhausen, M. ; Whalley, A and Taugner, R. (1986). Ultrastructure, renin status, contractile and electrophysiological properties of the afferent glomerular arteriole in the rat hydronephrotic kidney. Virchows Arch A. Path. Anat. 410:31-42.

3. Lidop,G.B.M. (1987). Morphological aspects of renin synthesis, storage and secretion. Kidney Int., 31 (Suppl. 20) : 18-24.

4. Davis, J.O. and Freeman, R.H. (1976). Mechanisms regulation renin release. Physiol. Rev. 56:1-56.

5. Hartroft, P.H and Hartroft, W.S. (1953). Studies on renal juuxtaglomerular cells. I. Variations produced by sodium chloride and deoxycorticosterone acetate. J. Exp. Med. 97:415-428.

6. Endes, P. ; Gomba, S. and Deveny, I. (1969). Specific staining and exact quantitative evaluation of the granulation of juxtaglomerular cells. Acta morph. Acad. Sci. Hung. $17: 46-53$.

7. Dauda, G. (1975). Correlation between juxtaglomerular index, kidney renin content and plasma renin concentration in the rat. Acta Physiol. Sci. Hung. 46:1932.

8. Cain, H.and Craus, B. (1976). The juxtaglomerular apparatus in malignant hypertension of man. Virch. Arch. A. Path. Histol. 372 : 11-28. 
The Iraqi J. Vet. Med. Vol. 21, No. (1), 1997.

9. Latta, H. ; White, F. ; Osvaldo, L. and Johnston, W. (1975). Unilateral renovascular hypertension in rats. Lab. Invest. $33: 379-384$.

10. Latta, H. and Lee, T.C. (1983). Effects of excessive sodium chloride on the juxtaglomerular apparatus and blood pressure of unineptectomized rats. Invest. 49 : 99 106.

11. AlAni, I.M. (1991). Frequency of juxtaglomerular granulated cells in diuretic (Frusemide) treated mice. Arab Gulf J. Scient. Res. 9:109-116.

12. Matschashi, H. (1979). Electron microscopic studies on the juxtaglomerular cells of the dehydrated mouse. Jap. J. Vet. Sci. 41: 283-293.

13. Taugner,R. ;Buhrle, C.P. ; Hackenthal, E. and Nobiling, R. (1984).Morphology of the juxtaglomerular apparatus and secretory mechanisms. Con. Nephrol. 43:76-101.

14. Harada, K. (1971). An aqueous acid and alkaline crystal violet technique. A rapid staining sequence for juxtaglomerular granules. Anat. ANZ. $128: 431-438$.

15. Bowie, D.J. (1936). A method for staining the pepsinogen granules in the gastric glands. Anat. Rec. 64:357-362.

16. Mouw, D. ; Bonjour, J. P. ; Molvin, R.I. and Vander, A (1971). Central action of angiotensin in stimulating $A D H$ release. Am. J. Physiol. 220 : 239-242.

17. Peter, S. and Mohring, J. (1978). The juxtaglomerular apparatus of rats with hereditary hypothalamic diabetes insipidus. Cell Tiss. Res. 188:335-339.

18. Yun,J. ; Kelly, G. and Bartter, F.C. (1977). Role of Prostaglandins in control of renin secretion in the dog. Cir. Res. 40:459-464.

19. Yum,J.(1979). On the control of renin release. Nephron 23:72-78. 
The Iraqi J. Vet. Med. Vol. 21, No. (1), 1997.

20. Dunn, M. J. ; Greely, H.P. ; Kinter, I.B. and Beeukes, R.(1978). Renal excretion of prostaglandins E2 and F2 in diabetes insipidus rats. Am. J. Physiol. 235: E 624-629.

21. Al-Ani, IM (1980). Anaigesic nephropathy in the gird and the mouse . Ph.D Thesis, The University of Leeds, England.

22. Dunn, M.J. (1976). Characterization of prostaglandin production in tissue culture of rat renal medullary cells. Prostaglandins $12: 37-42$.

23. Capelli, J.P. ; Wesson, L.G. and Aponte, G.E.(1970). A phylogenetic study of the renin - angiotensin system. Am. J. Physiol. 218. 1171-1178.

24. Hill,R.A. ; Coghlan, J. P. ; Scoggins, B. A and Ryan, G.B. (1983).Ultrastructural changes in the sheep renal juxtaglomerular apparatus in response to sodium depletion or loading. Pathology $15: 463-473$.

25. Tobian, I. (1960). Interrelationsilip of electrolytes, juxtglomerular cells and hypertension. Physiol. Rev. 40: 280-312.

26. Hartroft. P. M. (1968). The juxtaglomerular complex as an endocrine gland. In Bloodworth, J.M.B. (ed.), Endocrine pathology, Batimore, Williams \& Wilkins, PP. 641-677.

27. Mandal, A K (1979). Electron microscopy of the kidney. Plenum Medical book Co., England. 


\section{The Iraqi J. Vet. Med. Vol. 21, No. (1), 1997.}

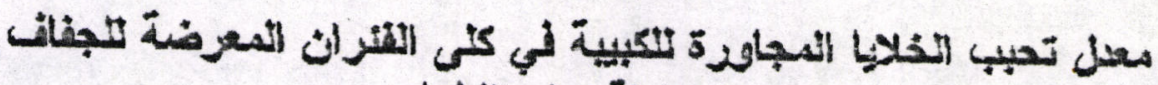

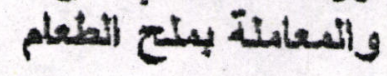

معاد مطنقب العاني " و مزلة حمز5 حسادي"

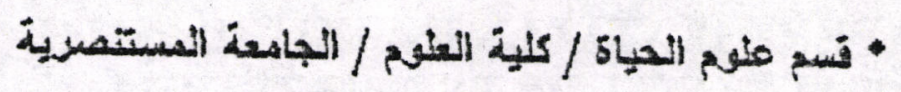

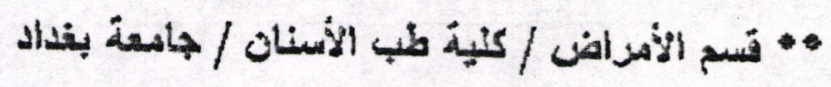

\section{الخلاصة}

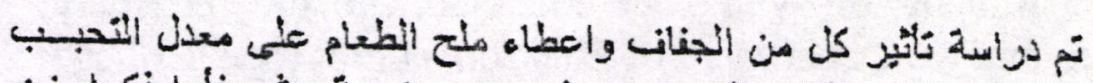

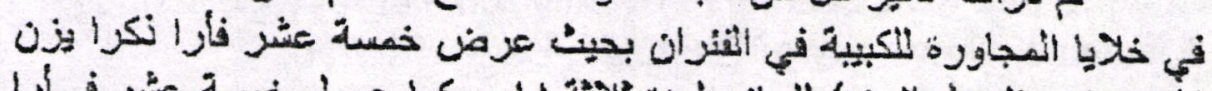

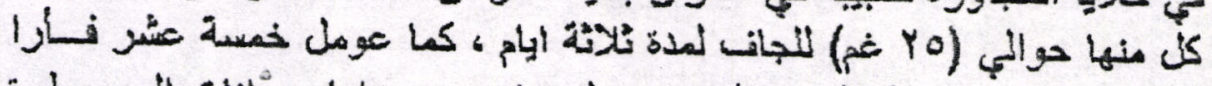

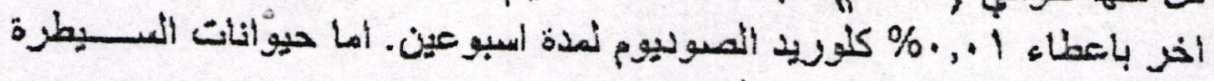

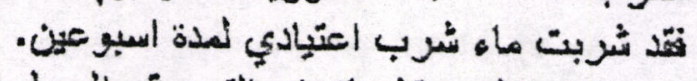

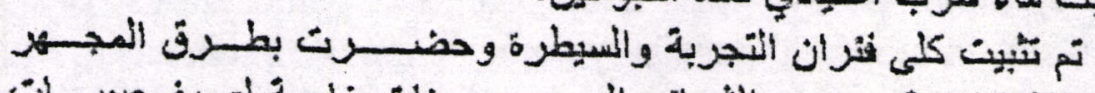

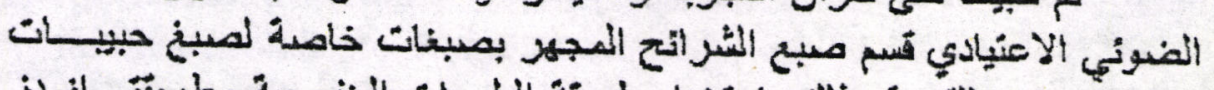

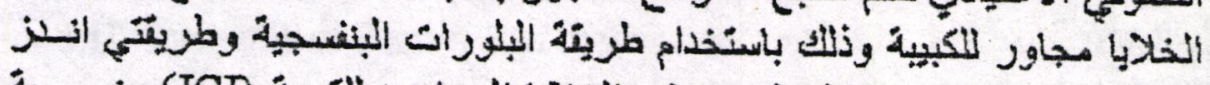

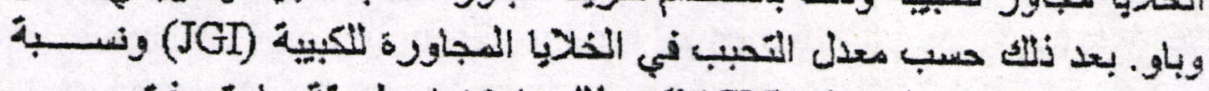

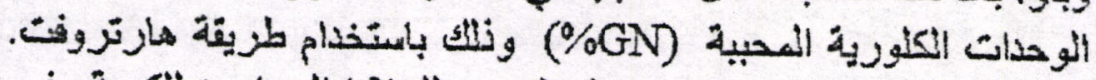

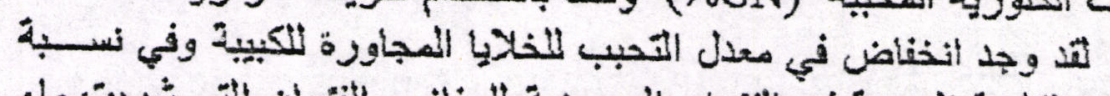

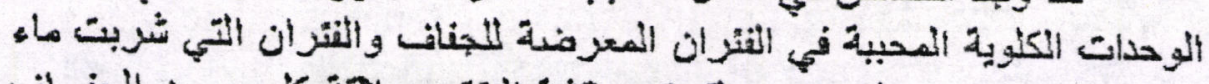

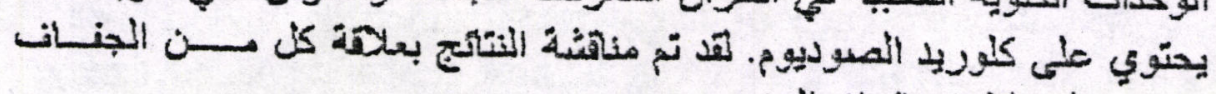

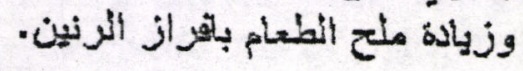

